\title{
Antimicrobial and Cytotoxicity Activities of Medicinal Plants against Salmonella gallinarum Isolated from Chickens
}

\author{
Mwanaisha Mkangara (D) $^{1}$ and Fulgence N. Mpenda ${ }^{2}{ }^{2}$ \\ ${ }^{1}$ Department of Science and Laboratory Technology, Dar es Salaam Institute of Technology, P. O. Box 2958, \\ Dar es Salaam, Tanzania \\ ${ }^{2}$ Department of Molecular Biology and Biotechnology, University of Dar es Salaam, P. O. Box 35179, Dar es Salaam, Tanzania \\ Correspondence should be addressed to Mwanaisha Mkangara; mkangaram72@gmail.com
}

Received 29 November 2021; Accepted 25 January 2022; Published 28 February 2022

Academic Editor: Sumanta Nandi

Copyright ( 2022 Mwanaisha Mkangara and Fulgence N. Mpenda. This is an open access article distributed under the Creative Commons Attribution License, which permits unrestricted use, distribution, and reproduction in any medium, provided the original work is properly cited.

\begin{abstract}
Medicinal plants have been the good source of treatment for different ailments of humans as well as animals for centuries. However, in Tanzania, few plants were investigated for their efficacy against various diseases of chickens. In the present study, four medicinal plants were investigated against Salmonella gallinarum isolated from chickens. The minimum inhibitory concentration (MIC) using the broth microdilution methods and minimum bactericidal concentration (MBCs) were used to evaluate the activities of plants against chicken salmonellosis. For the safety of chickens against the toxicity of plants, the cytotoxicity assay was determined using a brine shrimp lethality test. Aloe secundiflora leaf ethyl acetate (ALEA), Aloe rabaiensis leaf methanolic (ArM), Aloe rabaiensis leaf ethyl acetate (ArLEA), and Punica granatum leaf ethyl acetate (PGLEA) extracts exhibited the highest MIC $(0.3906 \mathrm{mg} / \mathrm{mL})$ and MBC $(3.125 \mathrm{mg} / \mathrm{mL})$, respectively. The Dolichos kilimandscharicus tuber ethyl acetate (DTEA) and Dolichos kilimandscharicus tuber pet ether (DTPE) extracts displayed MIC of $1.563 \mathrm{mg} / \mathrm{mL}$ and $12.50 \mathrm{mg} / \mathrm{mL}$ and MBC of $12.50 \mathrm{mg} / \mathrm{mL}$ and $25.50 \mathrm{mg} / \mathrm{mL}$, respectively. The highest $\mathrm{LC}_{50}$ values exhibited in Dolichos kilimandscharicus ranged from $7.937 \times 10^{-4} \mathrm{mg} / \mathrm{mL}$ to $7.242 \times 10^{-2} \mathrm{mg} / \mathrm{mL}$ for pet ether and methanolic extracts, respectively, while ALEA extract exhibited $\mathrm{LC}_{50}$ of $7.645 \times 10^{-3} \mathrm{mg} /$ $\mathrm{mL}$. Generally, the extracts with MIC $0.3906 \mathrm{mg} / \mathrm{mL}$ and MBC $3.125 \mathrm{mg} / \mathrm{mL}$ demonstrated the highest antibacterial activity with low toxicity efficient to manage chicken salmonellosis. Dolichos kilimandscharicus, which exhibited higher toxicity, warrants further investigation on insecticidal and anticancer agents.
\end{abstract}

\section{Introduction}

Salmonella spp. is a Gram-negative facultative anaerobic bacterium that belongs to the family Enterobacteriaceae [1]. The bacterium is zoonotic, affecting both chickens and humans [2]. The management of chickens with salmonellosis makes human the most affected individual than any other species [3]. However, salmonellosis in humans can also occur through eating contaminated food of animal origin including cattle, pork, and other poultry species $[4,5]$. Globally, there are 94 million cases of gastroenteritis associated with salmonellosis, which account for about 155,000 deaths each year [6-8]. The poultry sector alone accounts for up to $50 \%$ of salmonellosis outbreaks in humans [9]. Therefore, investigating for proper and affordable medication against salmonellosis in chickens is vital for the development of the chicken industry as well as the improvement of public health.

The increasing frequency of antibiotic resistance strains from bacterial, virus, fungi, and protozoa and failure of several drugs developed recently have shifted the global interest to plant-based products [10]. The fact is that medicinal plants are the primary source of bioactive compounds potential for the development of nutritional and pharmaceutical drugs $[11,12]$. Medicinal plants, unlike most antibiotics with a single target site, react with pathogens in multiple ways [13]. Different from antibiotics, bioactive compounds from medicinal plants can simultaneously disrupt the cellular membrane of a pathogen, stimulate the immune system of the host, protect intestinal mucosa from 
pathogen colonization, and promote the growth of beneficial bacteria [14]. For example, the bark of cinnamon (Cinnamomum zeylanicum) significantly reduced Salmonella enterica in cecal contents of infected chicken by disrupting bacterial cell membrane without affecting the total cecal endogenous population [15-17]. This observation demonstrates how bioactive compounds from medicinal plants promote beneficial bacteria, which later outcompete pathogens in resources and turn to improve the immune system of the host against diseases [18].

In Tanzania, chicken farming is constantly growing and contributes to $16 \%$ of the livestock GDP, $3 \%$ of agricultural sector GDP, and 1\% of national GDP [19]. However, infectious diseases, insufficient veterinary service, and unaccommodated prices of effective drugs mostly to the smallholder farmers are among the setbacks of chicken farming in the country [20].

Therefore, the study investigated the antibacterial and cytotoxicity activities of four Tanzanian medicinal plants, namely, Aloe secundiflora var sabolifera, Aloe rabaiensis, Punica granatum, and Dolichos kilimandscharicus against Salmonella gallinarum isolated from village chickens.

\section{Materials and Methods}

2.1. Plant Materials Collection. The plant materials were collected from August to September 2020. The leaf of Aloe secundiflora var sabolifera was obtained from Makuyuni, Arusha (3.1919 S, 36.5518 E, at altitude 1090 M), Aloe rabaiensis was obtained around Lake Jipe in Mwanga, Kilimanjaro (3.34882 S, 37.44202 E at altitude 718 M), Punica granatum leaf, fruit peel, and seed were obtained from Ngurdoto, Arusha (3.1919S, 36.5518 E, at altitude $1332 \mathrm{M}$ ), and Dolichos kilimandscharicus tuber was obtained from Moshi, Kilimanjaro (3.21 S, 37.2 E, at altitude $1220 \mathrm{M}$ ). Collected plants were identified by a Botanist from Tanzania Pesticide Research Institute (TPRI) and the voucher specimen number; ARH 403, PGH 507, DKH 212, and ASH 325 for A. rabaiensis, P. granatum, D. kilimandscharicus, and A. secundiflora, respectively, were deposited in the herbarium at TPRI.

2.2. Plant Materials Processing. Plant materials were washed with running tap water followed by distilled water to remove dust and soil. After washing, the leaves of A. secundiflora var sabolifera and A. rabaiensis, the tuber of D. kilimandscharicus, fruit peel, and leaves of $P$. granatum were chopped into small pieces and then air-dried separately under the shade for three weeks. The seeds of $P$. granatum were also air-dried under the shade separately without washing them. After drying the plant, materials were pulverized by a mill machine (Swinging Traditional Chinese Machine Pulverizer Diaxiang electronic equipment, DXF- 20D, China) into fine particles and kept in food bags and stored at room temperature $\left(25^{\circ} \mathrm{C}\right)$ for two weeks until utilization.

2.3. Chemical and Reagents. Nutrient agar and broth, Selenite F broth, Rappaport Vassiliadis broth, SIM media, Tryptone Soya Broth, MacConkey, Triple Sugar Iron (TSI), and Xylose Lysine Deoxycholate (XLD) agar and Buffered peptone water were sourced from Hi-Media Laboratories Pvt Ltd (Mumbai-India). Dimethyl sulfoxide (DMSO) was purchased from Sigma ${ }^{\circledR}$ (Poole, Dorset, UK). Analytical solvents were procured from RFCL Limited (Haryana-India). Brine Shrimp eggs were purchased from Aquaculture innovations (Grahamstown 6140, South Africa), and finally, Gentadox was purchased from Interchemie werken, Holland.

2.4. Extraction Procedure. The sequential extraction was done using solvents in order of increasing polarity. One hundred and twenty-five grams ( $125 \mathrm{~g}$ ) of each pulverized plant material was socked in extracting solvent $(1000 \mathrm{ml}$, $72 \mathrm{~h}$ ) in a shaker (Dragon lab, USA). The solvent used included pet ether, ethyl acetate, and methanol. The socked plant materials were then filtered using cotton wool and Whatman number 1 filter paper. The filtrates were concentrated using a Rotary evaporator (Heidolph, Germany), and later methanolic extract was further evaporated in a water bath at $40^{\circ} \mathrm{C}$ for $24 \mathrm{~h}$. The extracts obtained were weighed and kept in the refrigerator at $4^{\circ} \mathrm{C}$ for further use.

2.5. Faecal Samples Collection. A total of 360 village chickens aged 3 to 5 months were used in the study. The chickens were randomly picked from farmers in two wards, upland and lowland Tengeru-Arusha, Tanzania, from September 2020 to November 2020. An average of five chickens per household was used to collect $10 \mathrm{~g}$ of fecal samples from the cloaca of each chicken. The collection of fecal samples followed the diarrhea outbreak in adult chickens with white-yellowish coloration from the vent. The fecal sample was kept in a universal bottle containing $25 \mathrm{~mL}$ of buffered peptone water and incubated at $35^{\circ} \mathrm{C}$ for $18 \mathrm{~h}$.

2.6. Isolation of Salmonella spp. from Faecal Samples. The $1 \mathrm{~mL}$ of incubated fecal samples kept in buffered peptone water was enriched in $9 \mathrm{~mL}$ of Tryptone Soya Broth (TSB) and incubated at $37^{\circ} \mathrm{C}$ for $24 \mathrm{~h}$. Later, $0.5 \mathrm{~mL}$ of enriched broth was transferred in $9.5 \mathrm{~mL}$ of selective broth (Rappaport Vassiliadis broth) and incubated at $42^{\circ} \mathrm{C}$ for $48 \mathrm{~h}$. Consequently, the sterile cotton swab dipped in Rappaport Vassiliadis broth was streaked on MacConkey agar and Xylose Lysine Deoxycholate (XLD) agar and then incubated at $37^{\circ} \mathrm{C}$ for $24-36 \mathrm{~h}$ for a single pure colony. The colonies from MacConkey agar appeared colorless and translucent, while colonies from XLD agar appeared red with a black center after prolonged incubation.

2.7. Identification of Salmonella spp. by Biochemical Reaction. Biochemical identification of Salmonella species was made as described by Office International des Epizooties (OIE) Manual of diagnostic tests and vaccines for terrestrial animals, volume 1, 2008 [21]. 
2.8. Evaluation of Antibacterial Activity. Minimum inhibitory concentrations (MICs) were used to determine antimicrobial activity by microdilution methods using 96-well microtiter plates as per Eloff [22] with minor modifications. The plates were first preloaded with $50 \mu \mathrm{L}$ of the nutrient broth in each well followed by the addition of $50 \mu \mathrm{L}$ of the extract $(100 \mathrm{mg} / \mathrm{mL}$ prepared in $5 \%$ DMSO) into the first wells of each row to make a total volume of $100 \mu \mathrm{L}$ in the first wells. After thorough mixing, $50 \mu \mathrm{L}$ was drawn from each of the first row wells and put into the subsequent rows to the last wells, where the drawn $50 \mu \mathrm{L}$ was discarded. Thereafter, $50 \mu \mathrm{L}$ of Salmonella suspension (0.5Mac Farland standard turbidity, a suspension containing about $1.5 \times 10^{8} \mathrm{cfu} \mathrm{mL}^{-1}$ ) was then added to each well to make the final volume of $100 \mu \mathrm{L}$. The rows containing $0.05 \mathrm{mg} / \mathrm{mL}$ of Gentadox $(50 \mu \mathrm{L})$ were positive control used as a standard drug for chicken salmonellosis, and the wells, which contained DMSO (5\%), nutrient broth, and bacteria in triplicate form, were used as negative control. The plates were then incubated at $37^{\circ} \mathrm{C}$ for $24 \mathrm{~h}$. For each extract, MICs were determined by adding $10 \mu \mathrm{L}$ of $0.02 \%$ p-iodonitrotetrazolium (INT) chloride dye in each well, followed by incubation for $1 \mathrm{~h}$ at $32^{\circ} \mathrm{C}$. A color change indicated bacterial growth. Colour changed to pink is an indicator of the active growth of bacteria. The lowest concentration of extract, which showed no bacterial growth, was considered as MIC.

Minimum Bactericidal Concentration (MBC) was obtained by subculturing the contents from 96-well microtiter plates, where MIC value was read including all wells above the MIC. The wells, which showed no visible growth of Salmonella on McConkey agar, were considered as MBC. According to Qi et al. [23], the MBC is the lowest concentration of antibacterial agent required to kill more than $99.9 \%$ of the initial bacterial population, where no visible growth of the bacteria is observed on the agar plates.

2.9. Brine Shrimp Lethality Test. Cytotoxicity of the extracts was evaluated using brine shrimp of Artemia Salina Leach according to Meyer et al. [24], with minor modification. The medicinal plant extracts from $A$. secundiflora var sabolifera, A. rabaiensis, D. kilimandscharicus, and $P$. granatum were used in this study. The stock solution $(40 \mathrm{mg} / \mathrm{mL})$ was made by dissolving extracts to $5 \%$ DMSO to make different levels of concentration $(240,120,80,40$, 24 , and $8 \mu \mathrm{g} / \mathrm{mL}$ ) [25]. The levels of concentration were made from different volumes of a stock solution, which were then added in vials and adjusted to $5 \mathrm{~mL}$ of artificial seawater $(3.8 \mathrm{~g} / \mathrm{L})$. Each level of concentration was tested in duplicate. The negative control contained artificial seawater, brine shrimps, and DMSO (5\%) only. The positive control contained cyclophosphamides $(50 \mathrm{mg} / \mathrm{kg}$ ) prepared by dissolving $40 \mathrm{mg} / \mathrm{mL}$ similar to the stock solution. The light was used to incubate the vials for $48 \mathrm{~h}$ with a constant Oxygen gas supply. After this period, the dead larvae (dead nauplii) were counted, and the means mortality was subjected to analysis using Fig. P computer program (Biosoft Inc, USA).
2.10. Data Analysis. Mean results of brine shrimp mortality against logarithms of concentration were plotted using figure P computer program (Biosoft Inc., USA). Fig. P computer program gives regression equations, which were used to calculate $\mathrm{LC}_{16}, \mathrm{LC}_{50}, \mathrm{LC}_{84}$ values. The confidence intervals (95\% CI) were calculated according to Litchfield and Wilcoxon [26]. The $\mathrm{LC}_{50}$ value higher than $100 \mu \mathrm{g} / \mathrm{mL}$ equivalent to $1 \times 10^{-1} \mathrm{mg} / \mathrm{mL}$ was considered nontoxic and below it was considered toxic [27].

\section{Results and Discussion}

Antibacterial activity of plant extracts from A. secundiflora Engl var sabolifera, A. rabaiensis Rendle, D. kilimandscharicus Taub, and P. granatum Lin was evaluated against Salmonella gallinarum isolated from village chickens. Cytotoxicity activities of the above-named plant extracts were also evaluated against brine shrimps. The results of MIC and MBC of A. secundiflora leaf ethyl acetate, A. rabaiensis leaf ethyl acetate, A. rabaiensis leaf methanolic, $P$. granatum seed ethyl acetate, and $P$. granatum leaf ethyl acetate extracts revealed good antibacterial agents. The extracts showed higher activity and low toxicity as summarized in Tables 1 and 2. The details of biochemical reactions of isolated Salmonella spp., antibacterial, and cytotoxicity activities of named plants are explained hereunder.

3.1. Biochemical Reactions of Salmonella spp. Biochemical identification systems of bacteria are based on one or a combination of factors such as the utilization of carbon source, change in $\mathrm{pH}$ (carbohydrate is utilized $\mathrm{pH}$ acidic, nitrogen is released $\mathrm{pH}$ alkaline), or detection of growth of the organism [28]. Out of 360 samples of bacteria isolated from fecal samples of chickens and plated on two selective solid agars, $162(45 \%)$ isolates were preliminarily thought to be Salmonella species after morphological observation of colonies. The colonies were whitish, transparent, shining, and convex shape on MacConkey agar (Figure 1(a)). Similar colonies on xylose lysine deoxycholate (XLD) agar were transparent red with black centers (Figure 1(b)). Microscopically, the colons were pink rods after Gram staining (Figure 1(c)). According to Ranjbar et al. [29], XLD agar is among the sought media for the growth of Salmonella spp. The ingredients in XLD agar include sodium deoxycholate and an indicator system of phenol red combined with sugars (xylose, sucrose, and lactose), sodium thiosulphate, and iron all together with a slightly alkaline $\mathrm{pH}$ of 7.4 [30]. The carbohydrate catabolism of xylose during the growth of Salmonella lowers the $\mathrm{pH}$ from slightly alkaline to acidic, and the colonies grow with red coloration [31]. The black centers in colonies of Salmonella spp. are the result of an evolution of hydrogen sulfide from thiosulphate.

The confirmation of S. gallinarum was done by biochemical reactions. The red colon with a black center on XLD agar was then subcultured on nutrient agar. The pure colon from nutrient agar undergoes Gram staining, enzymes and sugar utilization test, hydrogen sulfide evolution, and motility tests. The biochemical tests identified 138 (38.3\%) 


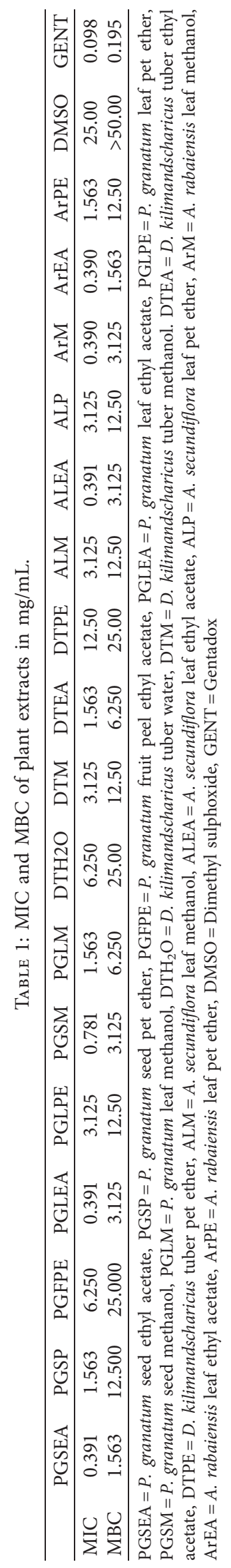


TABLE 2: Results of brine shrimps lethality test against plant extracts.

\begin{tabular}{lcccc}
\hline Sample code & LC $_{50}(\mathrm{mg} / \mathrm{mL})$ & $95 \%$ CI $(\mathrm{mg} / \mathrm{mL})$ Lower limit-Upper limit. & Regression equation & Regression coefficient $\left(R^{2}\right)$ \\
\hline DTW & $3.519 \times 10^{-3}$ & $(2.363-5.241) \times 10^{-3}$ & $Y=49.69 \operatorname{logx}+22.845$ & 0.9541 \\
ArW & $5.016 \times 10^{-1}$ & $(3.259-7.713) \times 10^{-1}$ & $Y=63.25 \operatorname{logx}-120.8$ & 0.9984 \\
ASM & $3.902 \times 10^{-1}$ & $(2.678-5.684) \times 10^{-1}$ & $Y=74.388 \operatorname{logx}-142.76$ & 00.9915 \\
DTM & $7.242 \times 10^{-2}$ & $(5.969-8.785) \times 10^{-2}$ & $Y=112.24 \operatorname{logx}-158.75$ & 0.9462 \\
PGFPEA & $1.720 \times 10^{-1}$ & $(1.418-2.086) \times 10^{-1}$ & $Y=145.2 \operatorname{logx}-274.6$ & 0.9954 \\
PGFPM & 1.245 & $\left(6.46 .8505 \times 10^{-1}\right)-2.396$ & $Y=42.763 \operatorname{logx}-82.357$ & 0.983 \\
ALPE & $1.896 \times 10^{-2}$ & $(1.451-2.477) \times 10^{-2}$ & $Y=81.124 \operatorname{logx}-53.664$ & 0.9744 \\
PGLM & $1.512 \times 10^{-1}$ & $(1.203-1.90 .129) \times 10^{-1}$ & $Y=105.93 \operatorname{logx}-180.89$ & 0.8841 \\
DTPE & $7.937 \times 10^{-4}$ & $\left(6.147 \times 10^{-4}\right)-\left(1.2911 \times 10^{-3}\right)$ & $Y=49.834 \operatorname{logx}+55$ & 1.0 \\
ALEA & $7.645 \times 10^{-3}$ & $\left(5.5784 \times 10^{-3}\right)-\left(1.048 \times 10^{-2}\right)$ & $Y=58.151 \operatorname{logx}-1.3704$ & 0.9129 \\
PGSM & $2.082 \times 10^{-1}$ & $\left(5.779 \times 10^{-2}\right)-\left(7.498 \times 10^{-1}\right)$ & $Y=80.141 \operatorname{logx}-135.8$ & 0.9033 \\
PGFPE & $5.505 \times 10^{-2}$ & $(4.691-6.460) \times 10^{-2}$ & $Y=151.57 \operatorname{logx}-213.85$ & 0.9808 \\
PGLEA & 1.245 & $\left(6.469 \times 10^{-1}\right)-2.396$ & $Y=42.763 \operatorname{logx}-82.357$ & 0.983 \\
PGLPE & $2.302 \times 10^{-1}$ & $(1.634-3.243) \times 10^{-1}$ & $Y=70.705 \operatorname{logx}-117.01$ & 0.8536 \\
DTEA & $1.468 \times 10^{-2}$ & $(1.079-1.998) \times 10^{-2}$ & $Y=64.321 \operatorname{logx}-25.053$ & 0.9899 \\
PGSEA & $6.428 \times 10^{-3}$ & $(4.4896-9.2022) \times 10^{-3}$ & $Y=55.168 \operatorname{logx}+5.421$ & 0.9485 \\
CLPM & $1.637 \times 10^{-2}$ & $(1.201-2.231) \times 10^{-2}$ & $Y=69.9680 \operatorname{logx}-34.9360$ & 0.994929 \\
\hline DTEA D & & &
\end{tabular}

$\mathrm{DTEA}=D$. kilimandscharicus tuber ethyl acetate, $\mathrm{DTPE}=D$. kilimandscharicus tuber pet ether, $\mathrm{ALM}=A$. secundiflora leaf methanol, $\mathrm{ALEA}=$ A. secundiflora leaf ethyl acetate, $\mathrm{ALP}=A$. secundiflora leaf pet ether, $\mathrm{ArW}=$ A. rabaiensis leaf water, $\mathrm{PGSEA}=P$. granatum seed ethyl acetate, $\mathrm{PGFPE}=P$. granatum fruit peel ethyl acetate, $\mathrm{PGLEA}=P$. granatum leaf ethyl acetate, $\mathrm{PGLPE}=P$. granatum leaf pet ether, $\mathrm{PGSM}=P$. granatum seed methanol, $\mathrm{PGLM}=P$. granatum leaf methanol, $\mathrm{DTH}_{2} \mathrm{O}=$ D. kilimandscharicus tuber water, $\mathrm{DTM}=$ D. kilimandscharicus tuber methanol, $\mathrm{CLPM}=$ Cyclophosphamide.

isolates as Salmonella gallinarum (Table 3). Out of 138 (38.3\%) isolates of S. gallinarum, a total of $60(16.7 \%)$ isolates were the cultures of fecal samples from upland Tengeru chickens and 78 (21.6\%) from lowland Tengeru chickens (Table 3). In reference to these findings, which require further investigations, probably the river flowing from highland Tengeru to lowland Tengeru might also be the other source of spread of Salmonella as the chickens were found scavenging around the river and use the river water as a source of drinking water.

Nonmotility test observed in Salmonella samples identified from this study grouped the bacteria into either Salmonella gallinarum or Salmonella pullorum. The fact is that nonmotile Salmonella species is a characteristic of only S. gallinarum and S. pullorum in all subspecies of Salmonella enterica [32]. The sugar utilization tests on S. gallinarum revealed ferment maltose, dulcitol, fructose, and dextrose and not sucrose or lactose in sugar utilization (Table 4). These findings corroborate Sannat et al. [33] who identified S. gallinarum after fermenting dulcitol, maltose, and glucose, and S. pullorum after fermenting rhamnose and glucose with gas butt not dulcitol and maltose. Therefore, the sugar utilization, Gram staining, enzymes reactions, and motility tests of the biochemically tested Salmonella spp. demonstrated the presence of S. gallinarum in 138 (38.3\%) samples of bacteria collected from 360 fecal samples of chickens in two wards (Tables 3 and 4).

3.2. Determination of Antibacterial Activity. Antibacterial activity of pet ether and ethyl acetate and methanolic extracts of A. secundiflora (leaf), A. rabaiensis (leaf), $P$. granatum (leaf, seed, and fruit peel), and D. kilimandscharicus (tuber) were evaluated against S. gallinarum isolated from chickens. Out of 17 extracts, 5 (29.41\%), namely, P. granatum seed and leaf ethyl acetate,
A. secundiflora leaf ethyl acetate, A. rabaiensis leaf methanolic, and A. rabaiensis leaf ethyl acetate extracts, indicated the highest antibacterial activity against S. gallinarum, with MIC value of $0.309 \mathrm{mg} / \mathrm{mL}$. However, 12 extracts $(70.59 \%)$ represented moderate antibacterial activity with their MIC ranging from $0.781 \mathrm{mg} / \mathrm{mL}$ to $12.5 \mathrm{mg} / \mathrm{mL}$. In comparison to the MIC, the MBCs of all plant extracts tested are two or three times their MICs (Table 1). The antibacterial activity illustrated from this study is supported by other scholars such as Kaingu et al. [34] who investigated the anticoccidial effects of Aloe secundiflora against Eimeria tenella in broiler chickens after preventing death and severity of bloody diarrhea. Others are Msoffe and Mbilu [35] who investigated A. secundiflora against the Candida albicans with inhibition zones of $11.46 \pm 0.69$ to $16.66 \pm 1.09 \mathrm{~mm}$ at the concentration of 20 to $100 \mu \mathrm{L}$, respectively. According to Waihenya et al. [36], the severity and mortality of chickens infected with Newcastle disease virus were significantly reduced after treating with Aloe secundiflora. On the other hand, Mariita et al. [37] studied the antitubercular of A. secundiflora and observed the lowest MIC of $0.5 \mathrm{mg} / \mathrm{mL}$, which inhibited $99 \%$ of Mycobacterium tuberculosis. The antibacterial activity of $A$. secundiflora was also revealed in P. aeruginosa, E. coli, S. aureus, and $S$. typhi with inhibition zones $\geq 9.00 \mathrm{~mm}$, and MIC value ranged from 3 to $11 \mathrm{mg} / \mathrm{mL}[8,38]$. The observable antimicrobial activities of Aloe secundiflora are attributed to a mixture of phenolic compounds mainly anthrones, chromones, and phenylpyrones, and their derivatives $[39,40]$. Similar to these findings, phytoconstituents in Aloe secundiflora revealed the presence of flavonoid catechins, which is capable of inhibiting the actions of DNA polymerase in bacteria and bind and damage the bacterial cell membrane, which finally increases permeability and leads to cell lysis [41, 42]. 


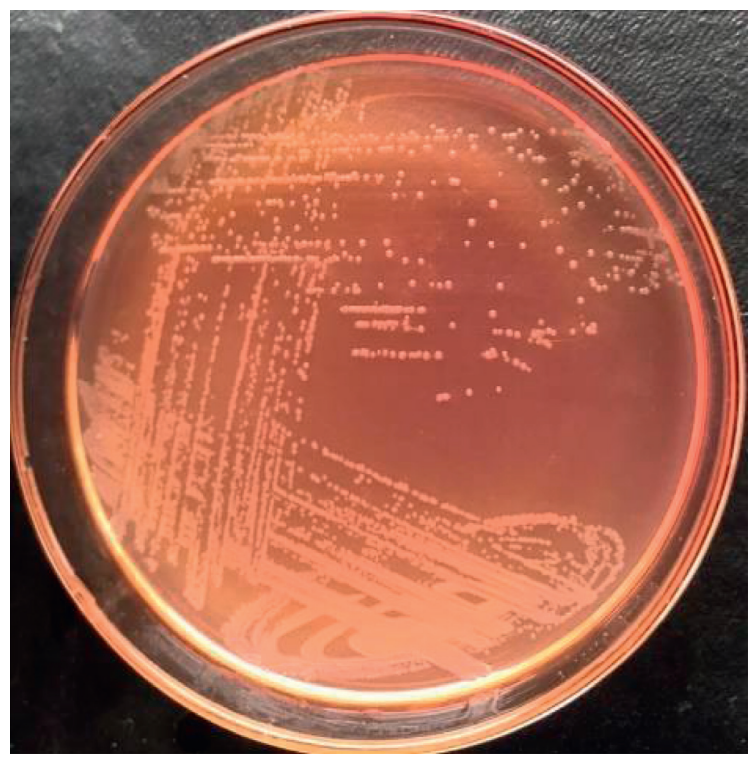

(a)

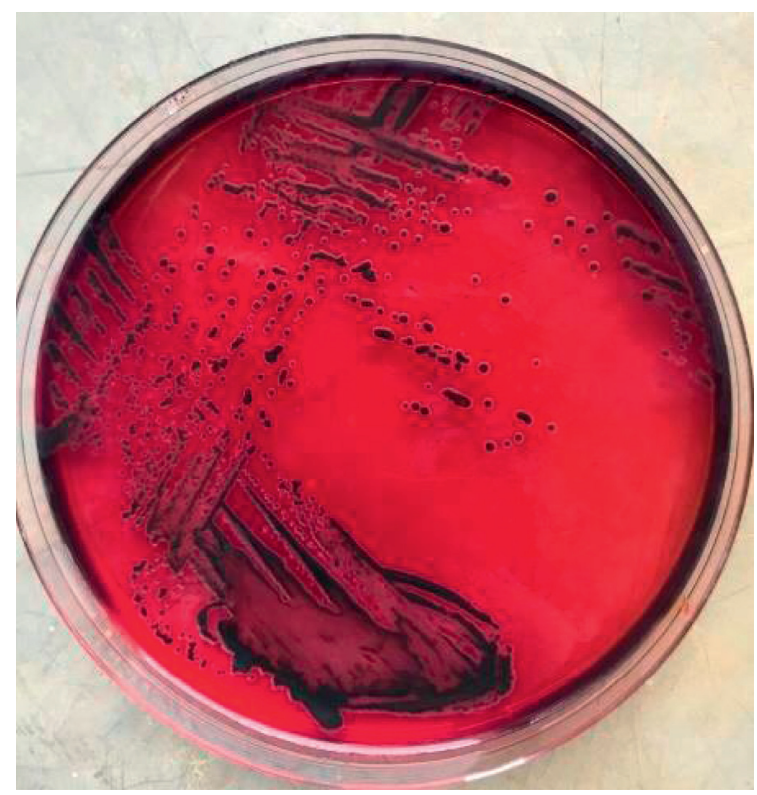

(b)

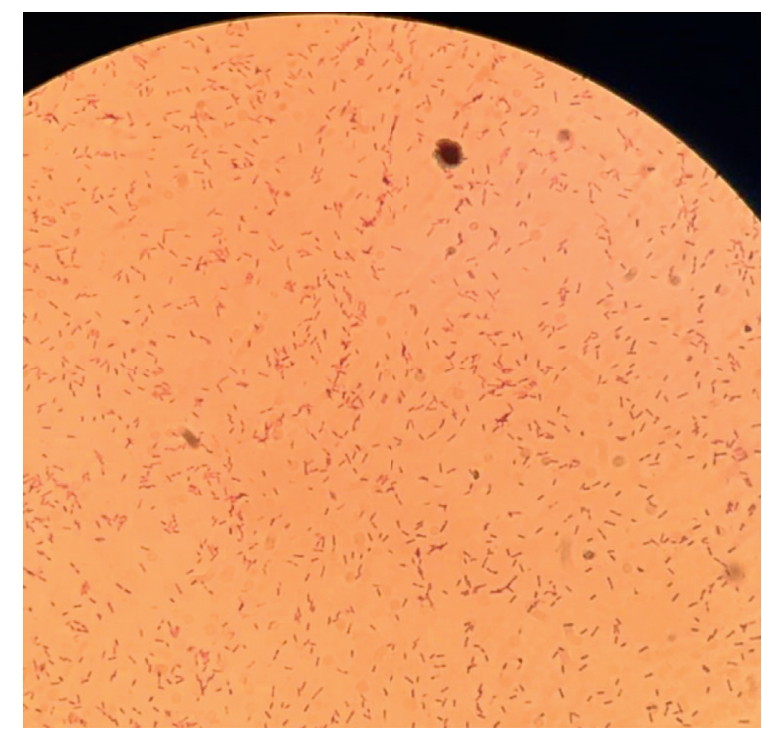

(c)

Figure 1: (a): Salmonella gallinarum colonies in MacConkey agar. (b) Salmonella gallinarum colonies in xylose lysine deoxycholate (XLD) agar. (c) Rod shaped of Salmonella gallinarum $(\times 100)$ after Gram staining.

TABle 3: Percentage of chickens with Salmonella spp. identified by microscopical and biochemical tests from both wards.

\begin{tabular}{lcccc}
\hline \multicolumn{2}{c}{ Microscopically } & \multicolumn{2}{c}{ Biochemical test } \\
\hline Salmonella isolates & Non-Salmonella isolates & S. gallinarum & Upland Tengeru & Lowland Tengeru \\
$162 / 360(45 \%)$ & $198 / 360(55 \%)$ & $138 / 360(38.3 \%)$ & $60 / 360(16.7 \%)$ & $78 / 360(21.6 \%)$ \\
\hline
\end{tabular}

Historically, Punica granatum is known for its therapeutic activity to ameliorate diseases since Roman times $[43,44]$. In traditional medicine, pomegranate leaves, flowers, roots, and fruit have been used to treat microbial infections, diarrhea, helminthiasis, dysentery, haemorrhage, acidosis, and respiratory and cardiac diseases $[45,46]$. In the present study, $P$. granatum showed the highest antibacterial activity against $S$. gallinarum with
MIC values ranging from $04500.390 \mathrm{mg} / \mathrm{mL}$ to $6.25 \mathrm{mg} / \mathrm{mL}$ (Table 1). A study by Haidari et al. [47] investigated $P$. granatum against the human influenza $A$ virus, and the findings were promising due to polyphenols from pomegranate with active ingredient punicalagin, ellagic acid, and hydrolyzable tannins. The study by Abou El-Nour [48] reported the antibacterial activity of pomegranate peel extract against $S$. typhi, E. coli, and $S$. aureus with inhibition 
TABLE 4: Biochemical reactions of Salmonella spp.

\begin{tabular}{lcc}
\hline Test & & Results \\
Motility & Upland Tengeru & Lowland Tengeru \\
Gram staining & Nonmotile & Nonmotile \\
Colon arrangement & Positive & Positive \\
Urease & Singly or pair & Singly or pair \\
Catalase & Negative & Negative \\
Oxidase & Positive & Positive \\
McConkey agar & Negative & Negative \\
TSI & Pale yellow transparent colony & transparent colony \\
$\mathrm{H}_{2}$ S production & Alkaline slant, acid butt & Pale yellow \\
Sugar utilization & Positive & Alkaline slant, acid butt \\
Maltose & & Positive \\
Dulcitol & Positive & Positive \\
Fructose & Positive & Positive \\
Sucrose & Positive & NT \\
Lactose & Negative & Negative \\
Dextrose & Negative & Negative \\
Glucose & Positive & Positive \\
Mannitol & Positive & Positive \\
Biotype & Positive & Positive \\
\hline
\end{tabular}

NT-Not tested.

zone ranging from 8 to $15 \mathrm{~mm}$. Similar findings by Duman et al. [49] reported antibacterial efficacy of $P$. granatum fruit peel extract against $V$. cholera, S. typhi, S. flexneri, S. dysenteriae, E. coli, and $S$. aureus with zones of inhibition ranging from 12 to $31 \mathrm{~mm}$. The observable activities in P. granatum are associated with punicalagin, ellagic acid, ellagitannins, and gallotannins, which are essential constituents in Pomegranate with antibacterial, antiviral, and antifungal properties [50-52].

Root and tuber of D. kilimandscharicus are known for antifungal and ant-molluscicidal properties attributed by saponins $[53,54]$. In this study, D. kilimandscharicus tuber extracts revealed the highest toxicity with $\mathrm{LC}_{50}$ values of $7.937 \times 10^{-4} \mathrm{mg} / \mathrm{mL}, 3.5192 \times 10^{-3} \mathrm{mg} / \mathrm{mL}, 1.468 \times 10^{-2} \mathrm{mg} /$ $\mathrm{mL}$, and $7.242 \times 10^{-2} \mathrm{mg} / \mathrm{mL}$ for pet ether, water, ethyl acetate, and methanolic extracts, respectively (Table 2 ). The results corroborated Sithole [55] who observed the efficacy of saponins as a natural detergent in D. Kilimandscharicus with antimicrobial and cholesterol-lowering anticancer compounds.

A. rabaiensis leaf methanolic and A. rabaiensis leaf ethyl acetate extracts inhibited the highest activity against S. gallinarum in in-vitro assay with MIC value of $0.390 \mathrm{mg} /$ $\mathrm{mL}$, and $\mathrm{MBC}$ ranged from 1.563 to $3.125 \mathrm{mg} / \mathrm{mL}$ (Table 1 ). The activity is due to phenolic constituents chromone, anthraquinone, and anthrone with antibacterial properties $[56,57]$.

According to Mushi et al. [58], MIC values are interpreted as follows: $0.05-0.5 \mathrm{mg} / \mathrm{mL}$ is strong activity, $0.6-1.5 \mathrm{mg} / \mathrm{mL}$ is moderate activity, and $>1.5 \mathrm{mg} / \mathrm{mL}$ is weak activity. The tested plants in this study have inhibited S. gallinarum in in vitro assays; thus, the study suggests further investigation of plants in the experimenting chickens to assess their effectiveness in in vivo assays.
3.3. Brine Shrimp Lethality Test. Cytotoxicity efficacies of plant extracts evaluated in this study are shown in Table 2. Generally, pet ether, water, and ethyl acetate extracts of D. kilimandscharicus were observed to have the highest toxicity against brine shrimp larva with $\mathrm{LC}_{50}$ value of $7.937 \times 10^{-4} \mathrm{mg} / \mathrm{mL}, 3.519 \times 10^{-3} \mathrm{mg} / \mathrm{mL}$, and $1.468 \times 10^{-2} \mathrm{mg} /$ $\mathrm{mL}$, respectively. Punica granatum seed ethyl acetate and A. Secundiflora leaf ethyl acetate exhibited toxicity with $\mathrm{LC}_{50}$ values of $6.428 \times 10^{-3} \mathrm{mg} / \mathrm{mL}$ and $7.645 \times 10^{-3} \mathrm{mg} / \mathrm{mL}$, respectively. However, their antibacterial activities are moderate. Therefore, the candidates qualify to be antitumor, anticancer, or insecticidal agents. According to Moshi et al. [27], the toxicity of plant extracts is termed nontoxic when $\mathrm{LC}_{50}>1 \times 10^{-1} \mathrm{mg} / \mathrm{mL}$, and vice versa. Punica granatum fruit peel methanol, $P$. granatum leaf ethyl acetate, $A$. rabaiensis leaf water, $A$. secundiflora leaf methanol, $P$. granatum leaf pet ether, $P$. granatum seed methanol, and $P$. granatum fruit peel ethyl acetate extracts have $\mathrm{LC}_{50}$ values of $1.245 \mathrm{mg} / \mathrm{ml}, 1.245 \mathrm{mg} / \mathrm{mL}$, $5.016 \times 10^{-1} \mathrm{mg} / \mathrm{mL}, 3.902 \times 10^{-1} \mathrm{mg} / \mathrm{mL}, 2.302 \times 10^{-1} \mathrm{mg} / \mathrm{mL}$, $2.082 \times 10^{-1} \mathrm{mg} / \mathrm{mL}, 1.720 \times 10^{-1} \mathrm{mg} / \mathrm{mL}$, and $1.512 \times 10^{-1} \mathrm{mg} /$ $\mathrm{mL}$, respectively (Table 2 ). These extracts are nontoxic and have shown higher antimicrobial efficacy against Salmonella species isolated from chickens.

\section{Conclusion}

The use of medicinal plants with varieties of secondary metabolites that react against pathogenic microbes in different ways to antibiotics is necessary for the management of S. gallinarum. The plants investigated in this study are worthwhile bacteriostatic as well as bactericidal in the management of bacterial infections including salmonellosis. The A. rabaiensis, A. secundiflora, and $P$. granatum revealed appreciable ranges of $\mathrm{MIC}$ and $\mathrm{MBC}$ as candidates with antibacterial properties. The D. kilimandscharicus extracts 
revealed low antibacterial activity against S. gallinarum. However, their cytotoxicity efficacies are highest compared to other plants. Therefore, D. kilimandscharicus warrants further investigation against tumors and insects.

\section{Data Availability}

The data are available from the corresponding author upon request.

\section{Ethical Approval}

This study was conducted following internationally accepted principles for laboratory animal use, handle, and care. The experimental procedure in this research complies with the University Animal Ethical Committee, which approved the study with ethical clearance reference number KNCHREC006 issued by the Nelson Mandela African Institution of Science and Technology, Kibong'oto Infectious Diseases Hospital, and Centre for Educational Development in Health.

\section{Conflicts of Interest}

The authors declare no conflicts of interest.

\section{Acknowledgments}

This work was supported by the African Development Bank (AfDB) under Grant number 21001550328. The local people from Arusha and Moshi, Tanzania, are thanked for their generous support in the exercise of collecting plants and chickens' fecal samples from their farms.

\section{References}

[1] M. P. Ryan, J. O’Dwyer, and C. C. Adley, "Evaluation of the complex nomenclature of the clinically and veterinary significant pathogen Salmonella," BioMed Research International, vol. 2017, Article ID 3782182, 13 pages, 2017.

[2] F. Shaltout and S. M. Nada, "Prevalence of salmonella in some chicken meat products," Benha Veterinary Medical Journal, vol. 36, no. 2, pp. 33-39, 2019.

[3] Y. Helmy, H. El-Adawy, and E. Abdelwhab, "A comprehensive review of common bacterial, parasitic and viral zoonoses at the human-animal interface in Egypt," Pathogens, vol. 6 , no. 3, p. 33, 2017.

[4] E. K. Barbour, D. B. Ayyash, W. Alturkistni et al., "Impact of sporadic reporting of poultry Salmonella serovars from selected developing countries," Journal of Infection in Developing Countries, vol. 9, pp. 1-7, 2015.

[5] W. A Abd El-Ghany, "Salmonellosis: A food borne zoonotic and public health disease in Egypt," Journal of Infection in Developing Countries, vol. 14, no. 7, pp. 674-678, 2020.

[6] S. E. Majowicz, J. Musto, E. Scallan et al., "The global burden of NontyphoidalSalmonellaGastroenteritis," Clinical Infectious Diseases, vol. 50, no. 6, pp. 882-889, 2010.

[7] M. D. Silva, S. Desta, and J. Stapleton, "Development of the chicken sector in the Tanzanian livestock master plan," Tanzania Livestock Master Plan Brief 7, ILRI, Nairobi, Kenya, 2017.
[8] B. Legba, D. Victorien, C. Yossounon et al., "Evaluation of invivo anti-Salmonella activity of Uvaria chamae, Lantana camara and Phyllantus amarus used in Benin, West Africa," BMC Veterinary Research, vol. 16, no. 49, pp. 1-18, 2020.

[9] P. Antunes, J. Mourão, J. Campos, and L. Peixe, "Salmonellosis: the role of poultry meat," Clinical Microbiology and Infections, vol. 22, no. 2, pp. 110-121, 2016.

[10] P. D. Gupta and T. J. Birdi, "Development of botanicals to combat antibiotic resistance," Journal of Ayurveda and Integrative Medicine, vol. 8, no. 4, pp. 266-275, 2017.

[11] R. S. Santhosh and B. Suriyanarayanan, "Plants: a source for new antimycobacterial drugs," Planta Medica, vol. 80, no. 1, pp. 9-21, 2014.

[12] U. Anand, N. Jacobo-Herrera, A. Altemimi, and N. Lakhssassi, "A comprehensive review on medicinal plants as antimicrobial therapeutics: potential avenues of biocompatible drug discovery," Metabolites, vol. 9, no. 11, p. 258, 2019.

[13] N. Silva and A. Fernandes Júnior, "Biological properties of medicinal plants: a review of their antimicrobial activity," Journal of Venomous Animals and Toxins Including Tropical Diseases, vol. 16, no. 3, pp. 402-413, 2010.

[14] S. Nabavi, A. Di Lorenzo, M. Izadi, E. Sobarzo-Sánchez, and M. M. Daglia, "Antibacterial effects of cinnamon: from farm to food, cosmetic and pharmaceutical industries," Nutridate, vol. 7, pp. 7729-7748, 2015.

[15] P. Ranasinghe, S. Pigera, G. S. Premakumara, P. Galappaththy, G. R. Constantine, and P. Katulanda, "Medicinal properties of "true"cinnamon (Cinnamomum zeylanicum): a systematic review," BMC Complementary and Alternative Medicine, vol. 13, no. 1, pp. 1-10, 2013.

[16] V. V. Ebani, B. Najar, F. Bertelloni, L. Pistelli, F. Mancianti, and S. Nardoni, "Chemical composition and in vitro antimicrobial efficacy of sixteen essential oils against Escherichia coli and Aspergillus fumigatus isolated from poultry," Journal of Veterinary Science, vol. 5, p. 62, 2018.

[17] A. L. Solarte, R. J. Astorga, F. C. de Aguiar, C. De Frutos, D. B. Barrero, and B. Huerta, "Susceptibility distribution to essential oils of Salmonella enterica strains involved in animal and public health and comparison of the typhimurium and enteritidis serotypes," Journal of Medicinal Food, vol. 21, no. 9, pp. 946-950, 2018.

[18] B. B. Petrovska, "Historical review of medicinal plants' usage," Pharmacological Reviews, vol. 6, p. 1, 2012.

[19] D. Komwihangilo, "The role of chicken in the Tanzanian economy and opportunities for development: an overview," in Proceedings of the ACGG Tanzania Innovation Platform Meeting, pp. 13-14, Dar es Salaam, Tanzania, July 2015.

[20] K. Ngongolo, E. Sigala, and S. Mtoka, "Community poultry project for conserving the wildlife species in magombera forest, Tanzania," Asian Journal of Research in Agriculture and Forestry, vol. 2, no. 4, pp. 1-7, 2019.

[21] International Office of Epizootics 2008 Biological Standards Commission, International Office of Epizootics, and International Committee, "Manual of diagnostic tests and vaccines for terrestrial animals: mammals, birds and bees," Office International des Epizooties, vol. 2, 2008.

[22] J. N. Eloff, "A sensitive and quick microplate method to determine the minimal inhibitory concentration of plant extracts for bacteria," Planta Medica, vol. 64, no. 8, pp. 711-713, 1998.

[23] L. Qi, Z. Xu, X. Jiang, C. Hu, and X. Zou, "Preparation and antibacterial activity of chitosan nanoparticles," Carbohydrate Research, vol. 339, no. 16, pp. 2693-2700, 2004. 
[24] B. Meyer, N. Ferrigni, J. Putnam, L. Jacobsen, D. Nichols, and J. L. Mclaughlin, "Brine shrimp: a convenient general bioassay for active plant constituents," Planta Medica, vol. 45, no. 5, pp. 31-34, 1982.

[25] M. Mkangara, M. Chacha, and P. Kazyoba, "Antimicrobial and cytotoxicity efficacy of commiphora swynnertonii (burtt) extracts," International Journal of Scientific Research, vol. 3, pp. 1611-1615, 2014.

[26] J. J. Litchfield and F. A. Wilcoxon, "Simplified method of evaluating dose-effect experiments," Journal of Pharmacology and Experimental Therapeutics, vol. 96, no. 2, pp. 99-113, 1949.

[27] M. Moshi, E. Innocent, J. Magadula et al., "Brine shrimp toxicity of some plants used as traditional medicines in Kagera region, northwestern Tanzania, Tanzania," Journal of Health Research, vol. 12, no. 1, pp. 63-67, 2010.

[28] B. Lal, S. Vijayakumar, S. Anandan, and B. Veeraraghavan, "Specimen collection, processing, culture, and biochemical identification of Acinetobacter spp," in Acinetobacter Baumannii, Humana Press, New York, NY, USA, 2 edition, 2019.

[29] V. R. Ranjbar, S. Basiri, and R. Abbasi-Kali, "Paratyphoid infection caused by Salmonella typhimurium in a pigeon flock (Columbia livia)," Iran. J. of Zoon. Diseas.vol. 4, no. 1, pp. 43-48, 2020.

[30] K. I. Swanson, "Evaluation of enrichment and identification media for isolation of common bovine Salmonella serotypes," Master's Thesis, Utah State University, Logan, Utah, 2020.

[31] T. Budiati, G. Rusul, A. F. AlKarkhi, R. Ahmad, and Y. M. Arip, "Prevalence of Salmonella spp. from Catfish (Clarias gariepinus) by using improvement isolation methods," International Proceedings of Chemical, Biological and Environmental Engineering, vol. 13, pp. 71-75, 2011.

[32] M. Bidhendi, P. Khaki, and N. Cheraghchi, "Study on phenotypic characteristics of Salmonella gallinarum and Salmonella pullorum isolates based on biochemical and antimicrobial susceptibility tests in Iran," Archives of Razi Institute, vol. 70, no. 3, pp. 171-177, 2015.

[33] C. Sannat, A. Patyal, N. Rawat et al., "Characterization of Salmonella gallinarum from an outbreak in Raigarh," Chhattisgarh. Veter. World.vol. 10, no. 2, p. 144, 2017.

[34] F. Kaingu, D. Liu, L. Wang, J. Tao, R. Waihenya, and H. Kutima, "Anticoccidial effects of Aloe secundiflora leaf extract against Eimeria tenella in broiler chicken," Tropical Animal Health and Production, vol. 49, no. 4, pp. 823-828, 2017.

[35] P. Msoffe and Z. Mbilu, "The efficacy of the crude extract of Aloe secundiflora on Candida albicans," African Journal of Traditional, Complementary and Alternative Medicines, vol. 6, no. 4, 2009.

[36] R. Waihenya, M. Mtambo, and G. Nkwengulila, "Evaluation of the efficacy of the crude extract of Aloe secundiflora in chickens experimentally infected with Newcastle disease virus," Journal of Ethnopharmacology, vol. 79, no. 3, pp. 299-304, 2002.

[37] R. M. Mariita, J. A. Orodho, P. O. Okemo, C. Kirimuhuzya, J. N. Otieno, and J. J. Magadula, "Methanolic extracts of Aloe secundiflora Engl. inhibits in vitro growth of tuberculosis and diarrhoea-causing bacteria," Pharmacognosy Research, vol. 3, no. 2, p. 95, 2011.

[38] H. Rachuonyo, P. Ogola, W. Arika, and J. Wambani, "Efficacy of crude leaf extracts of Aloe secundiflora on selected enteric bacterial pathogens and Candida albicans," Journal of Antimicrobiology, vol. 2, no. 112, p. 2, 2016.

[39] W. Rebecca, O. Kayser, H. Hagels, K. H. Zessin, M. Madundo, and N. Gamba, "The phytochemical profile and identification of main phenolic compounds from the leaf exudate of Aloe secundiflora by high-performance liquid chromatography-mass spectroscopy," Phytochemical Analysis: An International Journal of Plant Chemical and Biochemical Technology, vol. 14, no. 2, pp. 83-86, 2003.

[40] M. Mkangara, Bioactivity of medicinal plants against bacteria species associated with salmonellosis in chicken: case study in northern Tanzania, PhD Thesis, Nelson Mandela African Institution of Science and Technology, Arusha, Tanzania, 2020.

[41] A. López, M. de Tangil, O. Vega-Orellana, A. Ramírez, and M. Rico, "Phenolic constituents, antioxidant and preliminary antimycoplasmic activities of leaf skin and flowers of Aloe vera (L.) Burm. f.(syn. A. barbadensis Mill.) from the Canary Islands (Spain)," Molecules, vol. 18, no. 5, pp. 4942-4954, 2013.

[42] J. Sokoudjou, C. F. Siméon Pierre, G. D. Flavie et al., "Antisalmonella and antioxidant potential of hydroethanolic extract of Canarium schweinfurthii Engl. (Burseraceae) in Salmonella enterica serovar typhimurium-infected chicks," Asian Pacific Journal of Tropical Medicine, vol. 9, no. 11, p. 474, 2019.

[43] P. R. Bhandari, "Pomegranate (Punica granatum L). Ancient seeds for the modern cure? Review of potential therapeutic applications," International Journal of Nutrition, Pharmacology, Neurological Diseases, vol. 2, no. 3, p. 171, 2012.

[44] A. A. Mostafa, A. A. Al-Askar, K. S. Almaary, T. M. Dawoud, E. N. Sholkamy, and M. M. Bakri, "Antimicrobial activity of some plant extracts against bacterial strains causing food poisoning diseases," Saudi Journal of Biological Sciences, vol. 25, no. 2, pp. 361-366, 2018.

[45] M. Bagchi, S. Patel, S. Zafra-Stone, and D. Bagchi, "Selected herbal supplements and nutraceuticals," in Reproductive and Developmental Toxicology, Academic Press, Amsterdam, Germany, 1 edition, 2011.

[46] A. Lytou, E. Z. Panagou, and G. J. E. Nychas, "Development of a predictive model for the growth kinetics of aerobic microbial population on pomegranate marinated chicken breast fillets under isothermal and dynamic temperature conditions," Food Microbiology, vol. 55, pp. 25-31, 2016.

[47] M. Haidari, M. Ali, S. W. Casscells III, and M. Madjid, "Pomegranate (Punica granatum) purified polyphenol extract inhibits influenza virus and has a synergistic effect with oseltamivir," Phytomedicine, vol. 16, no. 12, pp. 1127-1136, 2009.

[48] M. M. Abou El-Nour, "Functional properties and medical benefits of pomegranate (Punica granatum L.) peels as agroindustrial wastes," Egyptian Journal of Experimental Biology, vol. 15, no. 2, pp. 377-392, 2019.

[49] A. D. Duman, M. Ozgen, K. S. Dayisoylu, N. Erbil, and C. Durgac, "Antimicrobial activity of six pomegranates (Punica granatum L.) varieties and their relation to some of their pomological and phytonutrient characteristics," Molecules, vol. 14, no. 5, pp. 1808-1817, 2009.

[50] S. H. Abdollahzadeh, R. Y. Mashouf, H. Mortazavi, M. H. Moghaddam, N. Roozbahani, and M. Vahedi, "Antibacterial and antifungal activities of Punica granatum peel extracts against oral pathogens," Journal of Dentistry, vol. 8, no. 1, p. 1, 2011.

[51] H. Saleh, A. Golian, H. Kermanshahi, and M. T. Mirakzehi, "Effects of dietary -tocopherol acetate, pomegranate peel, and pomegranate peel extract on phenolic content, fatty acid composition, and meat quality of broiler chickens," Journal of Applied Animal Research, vol. 45, no. 1, pp. 629-636, 2017. 
[52] D. Zhou, Z. H. Liu, D. M. Wang, D. W. Li, L. N. Yang, and W. Wang, "Chemical composition, antibacterial activity and related mechanism of valonia and shell from Quercus variabilis Blume (Fagaceae) against Salmonella paratyphi a and Staphylococcus aureus," BMC Complementary and Alternative Medicine, vol. 19, no. 1, pp. 1-12, 2019.

[53] C. Shava, M. Princess, M. Batanai, S. Simbarashe, C. Tariro, and M. Stanley, "Antibacterial and anticancer properties of Dolichos kilimandscharicus (Fabaceae)," Journal of Biologically Active Products from Nature, vol. 6, no. 2, pp. 112-135, 2016.

[54] S. Sithole, P. Mushonga, L. N. Nhamo, G. Fru Chi, and S. Mukanganyama, "Phytochemical fingerprinting and activity of extracts from the leaves of Dolichos kilimandscharicus (fabaceae) on jurkat-T cells," BioMed Research International, vol. 2020, Article ID 1263702, 21 pages, 2020.

[55] S. Sithole, "Isolation, purification and characterisation of antiproliferative phytochemicals from Dolichos kilimandscharicus (Fabaceae)," Master's thesis, University of Zimbabwe, Harare, Zimbabwe, 2017.

[56] J. H. Park and S. W. Kwon, "An epitome of chemical components and low molecular compounds," New Perspectives on Aloe, pp. 19-34, Springer, Berlin, Germany, 2006.

[57] M. Mkangara, M. Ernest, and C. Musa, "Evaluation of acute toxicity and sub-acute toxicity of the methanolic extract of Aloe rabaiensis Rendle in BALB/c mice," Journal of Medicinal Plants Research, vol. 13, no. 13, pp. 296-303, 2019.

[58] N. F. Mushi, Z. H. Mbwambo, E. Innocent, and S. Tewtrakul, "Antibacterial, anti-HIV-1 protease and cytotoxic activities of aqueous ethanolic extracts from Combretum adenogonium Steud. Ex A. Rich (Combretaceae)," BMC Complementary and Alternative Medicine, vol. 12, no. 1, p. 163, 2012. 